\title{
Respons Petani terhadap Program Asuransi Usaha Tani Padi (AUTP) di Kecamatan Adimulyo Kabupaten Kebumen
}

\author{
Farmers' Responses to Rice Farming Insurance Program (Autp) in Adimulyo Subdistrict Kebumen \\ Regency
}

\section{Rumiati Khasanah, Suwarto, Arip Wijianto}

Program Studi Penyuluhan dan Komunikasi Pertanian Fakultas Pertanian

Universitas Sebelas Maret

Jl. Ir. Sutami No.36 Kentingan Surakarta 57126 Telp/Fax (0271) 637457

Email: rumiatikhasanah@gmail.com

\begin{abstract}
This research aims to analyze the responses of farmers to the AUTP program; to analyze the factors affecting farmers' responses to the AUTP program; and to analyze the influence of factors affecting responses to farmers'responses in the AUTP program. This research was conducted in Adimulyo Subdistrict, Kebumen Regency with the consideration of Adimuluyo Subdistrict is one of the regions that has implemented the AUTP program. This research used quantitative methods and survey technique. The sampling technique used was proportional random sampling. The data sources used were primary and secondary data with methods of observation, interviews, documentation and recording. The analysis method used was multiple linear regression. The results showed that the farmers' responses to the program from the aspects of understanding, acceptance and implementation of the majority of farmers' responses were in the category of highly disagree with the program. Factors that can influence the responses of the majority were in the very low category, such as formal education, non-formal education, personal experience of rice farming, cultivated land area. Only the age factor was middle-aged, income was low, and mass media access was never. There was a significant influence between the independent variables to the dependent variable in the AUTP program. Independent variables that significantly affected were age $(X)$, nonformal education $\left(X_{3}\right)$, income $\left(X_{4}\right)$, personal experience of rice farming $\left(X_{5}\right)$, cultivated land area $\left(X_{6}\right)$ and mass media access $\left(X_{7}\right)$. Other variable that didn't significantly affected the responses of farmers in the AUTP program was formal education $\left(X_{2}\right)$.
\end{abstract}

Keywords: AUTP, Farmers' Responses, Kebumen, Multiple Linear Regression

Abstrak: Penelitian ini bertujuan untuk mengkaji respons petani terhadap program AUTP; mengkaji faktorfaktor yang mempengaruhi respons petani pada program AUTP; serta mengkaji pengaruh faktor-faktor yang mempengaruhi respons terhadap respons petani dalam program AUTP. Lokasi penelitian di Kecamatan Adimulyo, Kabupaten Kebumen dengan pertimbangan Kecamatan Adimuluyo merupakan salah satu wilayah yang telah melaksanakan program AUTP. Penelitian ini menggunakan metode kuantitatif dengan teknik survei. Teknik sampling yang digunakan adalah proportional random sampling. Sumber data yang digunakan adalah data primer dan sekunder dengan metode observasi, wawancara, dokumentasi dan pencatatan. Metode analisis data menggunakan uji regresi linier berganda. Hasil penelitian menunjukkan bahwa respons petani terhadap program dari aspek pemahaman, penerimaan dan pelaksanaan sebagian besar petani berada pada kategori sangat tidak setuju terhadap program. Faktor yang dapat mempengaruhi respons mayoritas berada pada kategori sangat rendah yaitu antara lain pendidikan formal, pendidikan non formal, pengalaman pribadi, luas lahan garapan. Hanya faktor umur berkategori tengah baya, pendapatan berkategori rendah, dan akses media massa berkategori tidak pernah. Terdapat pengaruh yang signifikan antara variabel independen terhadap variabel dependen dalam program AUTP. Variabel independen yang berpengaruh signifikan antara lain umur $\left(\mathrm{X}_{1}\right)$, pendidikan non formal $\left(\mathrm{X}_{3}\right)$, pendapatan $\left(\mathrm{X}_{4}\right)$, pengalaman pribadi $\left(\mathrm{X}_{5}\right)$, luas lahan garapan $\left(\mathrm{X}_{6}\right)$ dan akses media massa $\left(\mathrm{X}_{7}\right)$. Variabel lainnya yang tidak berpengaruh signifikan terhadap respons petani dalam program AUTP adalah pendidikan formal $\left(\mathrm{X}_{2}\right)$.

Kata Kunci: AUTP, Respons Petani, Kebumen, Regresi Linier Berganda 


\section{PENDAHULUAN}

Pertanian merupakan sektor terbesar kedua yang berperan penting sebagai penyumbang Produk Domestik Bruto (PDB) di Indonesia. PDB merupakan salah satu metode untuk menghitung pendapatan nasional. Menurut laporan Badan Pusat Statistik (2017), sektor pertanian, kehutanan dan perikanan menyumbang PDB sebesar 13,14 $\%$; diperingkat pertama ada industri pengolahan sebesar 38,03\%. Kontributor terbesar berikutnya adalah perdagangan besar dan reparasi mobil dan sepeda motor $13 \%$; dan konstruksi 10,4\%.

Namun sektor pertanian selalu dihadapkan pada risiko dan ketidakpastian yang tinggi. Risiko dan ketidakpastian tersebut berasal dari lingkungan alam seperti bencana alam (banjir dan kekeringan) dan eksploitasi organisme pengganggu tanaman (OPT) (Pasaribu, 2010; Sumaryanto dan Nurmanaf, 2007). Risiko yang dihadapi tersebut dapat berdampak pada berfluktuasinya pendapatan petani (Djunedi, 2016) dan dikhawatirkan akan berdampak pada stabilitas ketahanan pangan nasional, khususnya produksi dan ketersediaan bahan pangan pokok beras (Pasaribu, 2010). Sehingga perlu adanya upaya yang sistematis untuk meminimalkan risiko kerugian akibat ancaman tersebut.

Tahun 2015 pemerintah melalui Kementrian Pertanian dan Kementrian Keuangan menetapkan asuransi pertanian sebagai salah satu program ketahanan pangan nasional. Salah satu jenis asuransi pertanian tersebut adalah Asuransi Usahatani Padi (AUTP) yang dalam penyelenggaraannya dimaksudkan untuk melindungi kerugian nilai ekonomi usahatani padi akibat gagal panen, sehingga petani memiliki modal kerja untuk pertanaman berikutnya (Kementrian Pertanian, 2017). AUTP dapat menjadi program yang menarik dalam hubungannya dengan perubahan iklim global (Pasaribu, 2010).

Kebumen merupakan salah satu kabupaten yang telah melaksanakan program AUTP satu tahun setelah program itu digencarkan, yaitu pada tahun 2016, tepatnya musim tanam (MT) Oktober 2016-Maret 2017. Kecamatan Adimulyo merupakan salah satu dari 27 kecamatan di Kebumen yang mempunyai lahan sawah terluas yaitu 3.000 ha dan selalu ada petani yang mengasuransikan lahan usahataninya setiap musim tanam (MT). Permasalahan yang terjadi yaitu petani yang mengikuti program ini naikturun setiap musim tanamnya atau tidak tetap (Distapang Kebumen, 2017). Hal ini menunjukkan bahwa respons petani tidak selalu sama pada setiap musim tanam. Kondisi tersebut dibutuhkan suatu kajian yang dapat mengungkapkan respons petani terhadap program AUTP untuk mendapatkan gambaran mengapa petani menerima dan menolak program.

Ahmadi (2009) menyatakan bahwa respons merupakan bentuk kesiapan dalam menentukan sikap, baik dalam bentuk positif maupun negatif. Respons positif adalah respons yang menunjukkan atau memperlihatkan, menerima, mayakini serta melaksanakan normanorma yang berlaku dimana individu itu berada. Respons petani terhadap program AUTP di Kecamatan Adimulyo berbeda-beda antara MT dulu, sekarang dan yang akan datang. Hal tersebut akan mempengaruhi tindakan selanjutnya yang akan dilakukan petani terhadap program AUTP. Apabila respons petani positif, maka petani cenderung akan bersikap positif yang akan mendorong petani turut berpartisipasi. Namun apabila respons petani negatif, mereka cenderung akan bersikap negatif sehingga mendorong petani enggan turut berpartisipasi. Oleh sebab itu, respons petani terhadap program AUTP ini menjadi kajian yang menarik untuk diteliti lebih lanjut guna memberikan masukan bagi pengembangan program.

\section{METODE PENELITIAN}

Penelitian ini menggunakan pendekatan kuantitatif dengan teknik survei. Pemilihan lokasi secara sengaja (purposive) di Kecamatan Adimulyo, Kabupaten Kebumen dengan pertimbangan bahwa Kecamatan Adimulyo merupakan wilayah yang mempunyai luas lahan terluas dan luas lahan yang diasuransikan terbesar pada tahun musim tanam Oktober 2016-Maret 2017. Populasi dalam penelitian ini adalah petani yang tergabung dalam kelompok tani yang sudah mengikuti program AUTP di Desa Sugihwaras yang berjumlah 278 petani. Jumlah tersebut diambil dari 4 kelompok tani yaitu Setyo Wiji Dadi I, Setyo Wiji Dadi II, Setyo Budi Rahayu I 
dan Setyo Budi Rahayu II. Teknik sampling yang digunakan adalah proportional random sampling. Berdasarkan saran Rescoe (1928) dalam Sugiyono (2013) tentang ukuran sampel yang layak dalam penelitian adalah antara 30 sampai dengan 500, maka jumlah sampel yang digunakan dalam penelitian ini adalah sebanyak 60 orang. Sumber data yang digunakan adalah data primer dan sekunder dengan metode observasi, wawancara, dokumentasi dan pencatatan.

Metode analisis data dilakukan dengan uji regresi linier berganda yang analisisnya dititikberatkan dalam pengaruh. Selain itu, dilakukan beberapa uji lainnya yakni, uji validitas dengan pengambilan sampel sebanyak 30 responden dengan nilai $r_{\text {tabel }}$ sebesar 0,361 , kemudian dilakukan uji reliabilitas yang diukur dengan ketentuan nilai cronbach alpha > 0,60 . Hasil dari uji reliabilitas pada penelitian ini sebesar 0,716 lebih dari 0,60 yang berarti data penelitian dinyatakan reliabel. Sebelum dilakukannya analisis regresi, dilakukan uji asumsi klasik terlebih dahulu, yakni uji normalitas, uji hetereokskedisitas dan uji multikolinearitas. Hasil uji asumsi klasik dari penelitian ini menujukkan bahwa penelitian ini sudah memenuhi syarat untuk kemudian dianalisis dalam analisis pengaruh menggunakan regresi.

\section{HASIL DAN PEMBAHASAN}

Penelitian dilakukan di Kecamatan Adimulyo yang memiliki luas wilayah 4.343 ha, terdiri dari lahan sawah seluas 3.000 ha berupa lahan sawah dan lahan kering seluas 1.343 ha, dengan jumlah penduduk 34.438 jiwa yang ratarata penduduknya berada pada usia produktif (Kecamatan Adimulyo dalam Angka tahun 2018). Kecamatan Adimulyo didominasi oleh lahan sawah dan tegalan sehingga mayoritas penduduknya bekerja di sektor pertanian. Komoditas utama pertanian Kecamatan Adimulyo adalah padi.

Kecamatan Adimulyo khususnya Desa Sugihwaras merupakan wilayah yang memiliki ketinggian 0,1 mdpl (Monografi Desa Sugihwaras), sehingga rentan terjadi kebanjiran dan kekeringan. Pelaksanaan program AUTP di Kecamatan Adimulyo dalam upaya untuk meminimalkan risiko kerugian gagal panen akibat banjir, kekeringan dan serangan organisme pengganggu tanaman (OPT) dimulai dengan petani yang akan mengasuransikan lahan sawahnya dihimpun dalam satu data melalui kelompok tani, kemudian kelompok tani menyerahkan kepada penyuluh di UPTD Pertanian. Data yang sudah direkam kemudian diserahkan ke Dinas Pertanian Kabupaten yang kemudian menyerahkannya kepada PT. JASINDO Kantor Cabang Purwokerto.

\section{Respons Petani terhadap Program AUTP}

Respons petani terhadap program AUTP di Kecamatan Adimulyo, Kabupaten Kebumen diukur dengan mencatat jawaban responden dalam bentuk pertanyaan positif dan negatif mengenai program AUTP dari aspek penerimaan (kognitif), pemahaman (afektif) dan pelaksanaan (konatif). Respons petani terhadap program AUTP di Kecamatan Adimulyo, Kabupaten Kebumen disajikan pada Tabel 1.

Tabel 1. Distribusi Respons Petani terhadap Program AUTP di Kecamatan Adimulyo, Kabupaten Kebumen.

\begin{tabular}{llllrr}
\hline \multirow{2}{*}{ No } & \multirow{2}{*}{ Sub Variabel } & \multirow{2}{*}{ Kategori } & Skor & \multicolumn{2}{c}{ Distribusi } \\
\cline { 4 - 5 } & & & N & 37 \\
\hline 1 & Pemahaman (Kognitif) & Sangat Tidak Setuju & $15,00-25,86$ & 37 \\
3 & Penerimaan (Afektif) & Sangat Tidak Setuju & $15,00-32,67$ & 47 & 47 \\
4 & Relaksanaan (Konatif) & Sangat Tidak Setuju & $15,00-25,86$ & 37 & 37 \\
& Program AUTP secara total & Sangat Tidak Setuju & $45,00-98,03$ & 39 & 39 \\
\hline
\end{tabular}

Berdasarkan Tabel 1. dapat diketahui bahwa mayoritas respons petani terhadap program AUTP termasuk dalam kategori sangat tidak setuju sebanyak 39 responden $(65 \%)$. Hal ini menunjukkan bahwa program AUTP memiliki kesesuaian pernyataan-pernyataan terkait tujuan, 
manfaat dan teknis pelaksanaan yang dipaparkan dalam kuisioner. Hal ini sesuai dengan respons mayoritas petani responden yang ditinjau dari tiga aspek berikut yaitu pada aspek pemahaman sebanyak 37 responden $(61,67 \%)$ berada pada kategori sangat tidak setuju, aspek penerimaan sebanyak 47 responden $(78,33 \%$ berada pada kategori sangat tidak setuju dan aspek pelaksanaan sebanyak $37(61,67 \%)$ berada pada kategori sangat tidak setuju.

Adanya informasi yang kurang diantara petani sehingga sebagian besar petani belum mengetahui dan memahami program AUTP. Hal ini dikarenakan beberapa kelompok tani memang sudah vakum. Selain itu, anggapan petani bahwa lahan usahataninya tidak terlalu berisiko terhadap bencana banjir sehingga program AUTP dirasa tidak begitu penting. Namun demikian, masih terdapat petani yang berada pada kategori setuju sehingga mereka mengikuti program AUTP. Hal ini disebabkan beberapa petani percaya dan yakin bahwa program AUTP akan memberikan manfaat yang sesuai dengan maksud pemerintah menyelenggarakan program AUTP.

\section{Faktor-faktor yang Mempengaruhi Respons Petani terhadap Program AUTP}

Faktor-faktor yang dapat mempengaruhi respons petani antara lain umur, pendidikan formal, pendidikan non formal (Soekartawi, 1988; Enjorlas et.al., 2012), pendapatan (Siswandi dan Syakir, 2016), pengalaman pribadi (Azwar, 2013; Budianto, 2016), luas lahan garapan (Suratiyah, 2009) dan akses media massa (Azwar, 2013;Ban dan Hawkins, 1999). Berikut faktor-faktor yang dapat mempengaruhi respons petani terhadap program AUTP dapat dilihat pada Tabel 2.

Tabel 2. Distribusi Faktor-faktor yang Mempengaruhi Respons Petani terhadap Program AUTP di Kecamatan Adimulyo, Kabupaten Kebumen.

\begin{tabular}{llllrr}
\hline \multirow{2}{*}{ No } & Variabel & \multirow{2}{*}{ Kategori } & Skor & \multicolumn{2}{c}{ Distribusi } \\
\cline { 4 - 6 } & & Tengah Baya & $45-53$ & 27 & 45,00 \\
2 & Pendidikan Formal & Sangat Rendah & $2,0-7,5$ & 30 & 50,00 \\
3 & Pendidikan Non Formal & Sangat Rendah & $0,0-2,0$ & 49 & 81,67 \\
4 & Pendapatan & Rendah & $\leq$ Rp 6 juta & 27 & 45,00 \\
5 & Pengalaman Pribadi & Sangat Rendah & $5,00-13,75$ & 23 & 38,33 \\
6 & Luas Lahan Garapan & Sangat Rendah & $0,20-9,15$ & 41 & 68,33 \\
7 & Akses Media Massa & Tidak Pernah & $7,000-10,981$ & 60 & 100,00 \\
\hline
\end{tabular}

Berdasarkan Tabel 2. dapat diketahui bahwa hampir semua variabel faktor berada pada kategori sangat rendah. Hanya variabel umur, pendapatan dan akses media massa yang kategorinya berbeda. Fakta di lapang, mayoritas responden pada penelitian ini memiliki umur pada kategori tengah baya yaitu sebanyak 27 responden (45\%). Sehingga dapat dikatakan cenderung lebih cepat mengadopsi inovasi baru yang ada karena umurnya yang masih tergolong muda. Umur responden akan memberikan pengaruh terhadap respons petani terhadap program AUTP baik berupa respons positif maupun negatif. Hasil penelitian ini sesuai dengan pernyataan Enjorlas et.al. (2012) dan Budianto (2016) yang menyebutkan bahwa umur merupakan faktorfaktor yang mempengaruhi seorang individu merespon rangsangan.

Berbeda dengan umur, pendidikan formal petani yang berada pada kategori sangat rendah. Mayoritas petani yang menjadi responden dalam penelitian ini hanya berpendidikan pada tingkat SD yaitu sebanyak 30 responden (50\%), sehingga antusias petani dalam mengambil keputusan untuk mengikuti suatu kegiatan pun cenderung kurang. Hal ini berpengaruh terhadap respons petani terhadap program AUTP yang rendah. Hasil penelitian ini selaras dengan pendapat Soekartawi (1988) yang menyebutkan bahwa pendidikan yang tinggi relatif lebih cepat melaksanakan inovasi baru, begitupun sebaliknya. 
Begitupun dengan pendidikan non formal petani yang berada pada kategori sangat rendah yaitu sebanyak 49 responden $(81,67 \%)$. Pendidikan non formal dalam penelitian ini dilihat berdasarkan frekuensi petani mengikuti penyuluhan pertanian. Pendidikan non formal yang berkaitan dengan program AUTP tidak menyeluruh disampaikan kepada petani di Desa Sugihwaras. Hanya diambil perwakilan saja setiap kelompoknya yaitu pengurus kelompok tani. Kemudian dari pengurus kelompok tani menyampaikan kepada anggotanya. Akan tetapi, sebagian besar kelompok tani di Desa Sugihwaras sudah tidak aktif dalam keberjalanannya, sehingga informasi terkait bidang pertanian khususnya program AUTP akan berhenti di pengurus yang mewakili penyuluhan.

Lain halnya dengan variabel pendapatan. Pendapatan responden dalam satu musim tanam berada pada kategori rendah yaitu sebanyak 27 responden $(45 \%)$. Hal ini dikarenakan luas lahan garapan yang sempit dan hasil panen yang tidak selalu baik karena seringnya terkena banjir. Menurut Lionberger dalam Mardikanto (2009), yang mengatakan bahwa petani dengan tingkat pendapatan yang semakin tinggi biasanya akan semakin cepat merespons inovasi.

Variabel pengalaman pribadi berada pada kategori yang sama dengan umur, pendidikan formal dan pendidikan non formal. Sebanyak 23 responden $(38,33 \%)$ berada pada kategori sangat rendah. Mayoritas petani baru berusahatani kurang lebih 10 tahunan. Azwar (2013) menyatakan bahwa pengalaman pribadi yang telah dan sedang dialami akan ikut membentuk dan mempengaruhi penghayatannya terhadap stimulus sosial.

Sama halnya dengan variabel umur, pendidikan formal. pendidikan non formal dan pengalaman pribadi. Luas lahan garapan berada pada kategori sangat rendah yaitu sebanyak 41 responden $(68,33 \%)$. Mayoritas luas lahan usahatani milik responden hanya berkisar antara 0,1 Ha hingga 0,5 Ha dengan maksimal 5 bagian/ persil. Suratiyah (2009) yang mengatakan bahwa semakin luas garapan usahataninya, semakin besar pendapatannya yang akan mempengaruhi petani untuk bisa semakin cepat merespons halhal baru, begitupun sebaliknya.

Berbeda dengan variabel yang lainnya. Akses media massa berdasarkan Tabel 2 dapat diambil penjelasan bahwa semua responden mempunyai tingkat akses media massa dalam kategori tidak pernah yaitu dengan presentase sebesar $100 \%$. Hal tersebut menunjukkan bahwa semua responden mempunyai minat yang sangat rendah dalam menyimak media massa yang ada. Hal lain yang menjadikan akses media massa tidak pernah dikarenakan minimnya informasi seputar bidang pertanian yang tersaji dalam sebuah media massa. Informasi yang diakses oleh petani biasanya berupa informasi yang menghibur, seperti menonton sinetron di televisi.

Pengaruh Umur $\left(\mathbf{X}_{1}\right)$, Pendidikan Formal $\left(\mathbf{X}_{2}\right)$, Pendidikan Non Formal $\left(\mathbf{X}_{3}\right)$, Pendapatan $\left(\mathbf{X}_{4}\right)$, Pengalaman Pribadi $\left(\mathbf{X}_{5}\right)$, Luas Lahan Garapan $\left(X_{6}\right)$ dan Akses Media Massa $\left(X_{7}\right)$ terhadap Respons Petani pada Program AUTP.

$\mathrm{Y}=-62,930+0,187 \mathrm{X}_{1}+0,140 \mathrm{X}_{2}+16,554 \mathrm{X}_{3}+$ $3,531 X_{4}+0,174 X_{5}-5,929 X_{6}+13,923 X_{7}+\mu$

Keterangan:

Respons Petani, $\mathrm{X}_{1}$ : Umur, $\mathrm{X}_{2}$ : Pendidikan Formal, $\mathrm{X}_{3}$ : Pendidikan Non Formal, $\mathrm{X}_{4}$ : Pendapatan, $\mathrm{X}_{5}$ : Pengalaman Pribadi, $\mathrm{X}_{6}$ : Luas Lahan Garapan, $\mathrm{X}_{7}$ : Akses Media Massa, $\mu$ : Faktor Lain yang Tidak Diteliti

Beberapa uji yang dilakukan dalam analisis regresi linier berganda adalah uji $\mathrm{F}$, uji t dan uji koefisien determinasi $\left(\mathrm{R}^{2}\right)$. Berdasarkan uji koefisien determinasi $\left(\mathrm{R}^{2}\right)$ diperoleh hasil analisis nilai Adjusted ${ }^{2}$ adalah sebesar 0,548. Artinya, variabel independen seperti umur $\left(\mathrm{X}_{1}\right)$, pendidikan formal $\left(\mathrm{X}_{2}\right)$, pendidikan non formal $\left(\mathrm{X}_{3}\right)$, pendapatan $\left(\mathrm{X}_{4}\right)$, pengalaman pribadi $\left(\mathrm{X}_{5}\right)$, luas lahan garapan $\left(\mathrm{X}_{6}\right)$ dan akses media massa $\left(\mathrm{X}_{7}\right)$ dapat menjelaskan variabel dependen (respons petani terhadap program AUTP) sebesar $54,8 \%$ sedangkan sisanya $45,2 \%$ diterangkan faktor lain yang tidak diteliti. Nilai ${ }^{2}$ yang lebih dari $50 \%$ pada hasil analisis koefisien determinasi menjelaskan bahwa variabel-variabel independen hampir dapat memberikan semua informasi yang dibutuhkan untuk memprediksi variabel-variabel dependen (Alghifari, 2000;Ghozali, 2001).

Berdasarkan hasil uji $\mathrm{F}$ penelitian ini diperoleh nilai $p$ value $\leq \alpha$ atau $0,000 \leq 0,05$. Hal tersebut bermakna bahwa $\mathrm{H}_{0}$ ditolak dan $\mathrm{H}_{\mathrm{a}}$ diterima. Artinya variabel independen umur $\left(\mathrm{X}_{1}\right)^{\mathrm{a}}$, pendidikan formal $\left(\mathrm{X}_{2}\right)$, pendidikan non formal 
$\left(\mathrm{X}_{3}\right)$, pendapatan $\left(\mathrm{X}_{4}\right)$, pengalaman pribadi $\left(\mathrm{X}_{5}\right)$, luas lahan garapan $\left(\mathrm{X}_{6}\right)$ dan akses media massa $\left(X_{7}\right)$ mempunyai pengaruh yang signifikan secara bersama-sama (serentak) terhadap variabel dependen respons petani terhadap program AUTP. Hasil uji t penelitian ini dapat dilihat pada Tabel 3.

Tabel 3. Hasil Uji Parsial (Uji t) terhadap variable Y

\begin{tabular}{llrrrr}
\hline \multicolumn{5}{c}{ Heteroskedastisitas Model (STDLIN) } \\
\hline No & Variabel & B & Standard Error & Sig & Keterangan* \\
\hline & (Constant) & $-62,930$ & 27,490 & 0,022 & Signifikan \\
1 & Umur & 0,187 & 0,853 & 0,028 & Signifikan \\
2 & Pendidikan Formal & 0,140 & 0,104 & 0,179 & Tidak Signifikan \\
3 & Pendidikan Non Formal & 16,554 & 1,950 & 0,000 & Signifikan \\
4 & Pendapatan & 3,531 & 1,435 & 0,014 & Signifikan \\
5 & Pengalaman Pribadi & 0,177 & 0,721 & 0,016 & Signifikan \\
6 & Luas Lahan Garapan & $-5,929$ & 2,168 & 0,006 & Signifikan \\
7 & Akses Media Massa & 13,923 & 3,751 & 0,000 & Signifikan \\
\hline
\end{tabular}

Berdasarkan Tabel 3. berikut ini penjelasannya.

\section{Pengaruh Umur $\left(X_{1}\right)$ terhadap Respons Petani pada Program AUTP}

Nilai $p$ value atau sig pada variabel $\mathrm{X}_{1}$ sebesar 0,028. $p$ value $\leq \alpha$ yaitu $0,028 \leq 0,050$. Maka $\mathrm{H}_{0}$ ditolak dan $\mathrm{H}_{\mathrm{a}}$ diterima. Artinya umur secara parsial berpengaruh signifikan terhadap respons petani pada program AUTP dengan tingkat kepercayaan 95\%. Hasil penelitian ini sesuai dengan pernyataan Enjorlas et.al. (2012) dalam penelitiannya yang mengatakan bahwa umur mempengaruhi seorang individu merespons rangsangan suatu objek.

\section{Pengaruh Pendidikan Formal $\left(\mathrm{X}_{2}\right)$ terhadap Respons Petani pada Program AUTP}

Nilai $p$ value atau sig pada variabel $\mathrm{X}_{2}$ sebesar 0,179 . $p$ value $>\alpha$ yaitu $0,179>0,05$. Maka $\mathrm{H}_{0}$ diterima dan $\mathrm{H}_{\mathrm{a}}$ ditolak. Artinya pendidikan formal secara parsial tidak berpengaruh signifikan terhadap respons petani pada program AUTP dengan tingkat kepercayaan 95\%. Hasil penelitian dikatakan sesuai dengan pendapat yang disampaikan oleh Wijayanti et.al. (2015) dalam penelitiannya yang mengatakan bahwa tingkat pendidikan tidak berpengaruh signifikan terhadap respons petani.

Pengaruh Pendidikan Non Formal $\left(\mathrm{X}_{3}\right)$ terhadap Respons Petani pada Program AUTP

Nilai $p$ value atau sig pada variabel $\mathrm{X} 3$ sebesar $0,000 . p$ value $\leq \alpha$ yaitu $0,000 \leq$
0,05. Maka $\mathrm{H}_{0}$ ditolak dan $\mathrm{H}_{\mathrm{a}}$ diterima. Artinya pendidikan non formal secara parsial mempunyai pengaruh signifikan terhadap respons petani dengan tingkat kepercayaan 95\%. Hasil penelitian ini selaras dengan pernyataan Soekartawi (1988) yang menyebutkan bahwa agen penyuluh dapat membantu petani memahami besarnya pengaruh struktur sosial ekonomi dan teknologi untuk mencapai kehidupan yang lebih baik dan menemukan cara mengubah situasi yang menghalangi untuk mencapai tujuan tersebut.

\section{Pengaruh Pendapatan $\left(\mathrm{X}_{4}\right)$ terhadap Respons Petani pada Program AUTP}

Nilai $p$ value atau sig pada variabel $\mathrm{X}_{4}$ sebesar 0,014. $p$ value $\leq \alpha$ yaitu $0,014 \leq$ 0,05 . Maka $\mathrm{H}_{0}$ ditolak dan $\mathrm{H}_{\mathrm{a}}$ diterima. Artinya pendapatan secara parsial mempunyai pengaruh yang signifikan terhadap respons petani dengan tingkat kepercayaan 95\%. Hasil penelitian ini sesuai dengan pendapat Farzaneh et.al. (2017) yang menyebutkan bahwa tingginya pendapatan akan mempengaruhi penerimaan petani terhadap asuransi pertanian.

\section{Pengaruh Pengalaman Pribadi $\left(\mathrm{X}_{5}\right)$ terhadap Respons Petani pada Program AUTP}

Nilai $p$ value atau sig pada variabel $\mathrm{X}_{5}$ sebesar 0,016 . $p$ value $\leq \alpha$ yaitu $0,016 \leq 0,05$. Maka $\mathrm{H}_{0}$ ditolak dan $\mathrm{H}_{\mathrm{a}}$ diterima. Artinya pengalaman pribadi secara parsial mempunyai pengaruh 
signifikan terhadap respons petani dengan tingkat kepercayaan 95\%. Sesuai dengan pendapat yang disampaikan oleh Rozalina dan Tusiah (2015) yang mengatakan bahwa pengalaman pribadi berpengaruh signifikan terhadap respons petani. Pengaruh yang signifikan ini dapat terjadi karena petani yang memiliki pengalaman lebih lama dalam bidang pertanian akan sangat berpengalaman dalam urusan pertanian.

\section{Pengaruh Luas Lahan Garapan $\left(\mathrm{X}_{6}\right)$ terhadap Respons Petani pada Program AUTP}

Nilai $p$ value atau sig pada variabel $\mathrm{X}_{6}$ sebesar 0,006. $p$ value $\leq \alpha$ yaitu $0,006 \leq 0,05$. Maka $\mathrm{H}_{0}$ ditolak dan $\mathrm{H}_{\mathrm{a}}$ diterima. Artinya luas lahan garapan secara parsial mempunyai pengaruh yang signifikan terhadap respons petani dengan tingkat kepercayaan 95\%. Hasil penelitian ini sesuai dengan pendapat yang disampaikan oleh Rozalina dan Tusiah (2015) yang mengatakan bahwa luas lahan garapan berpengaruh signifikan terhadap respons petani.

\section{Pengaruh Akses Media Massa $\left(X_{7}\right)$ terhadap Respons Petani pada Program AUTP}

Nilai $p$ value atau sig pada variabel $\mathrm{X}_{7}$ sebesar 0,022 . $p$ value $\leq \alpha$ yaitu $0,022 \leq 0,05$. Maka $\mathrm{H}_{0}$ ditolak dan $\mathrm{H}_{\mathrm{a}}$ diterima. Artinya akses media massa secara parsial mempunyai pengaruh yang signifikan terhadap respons petani dengan tingkat kepercayaan 95\%. Hasil penelitian ini sesuai dengan pernyataan Azwar (2013) yang menyatakan bahwa sebagai sarana komunikasi, berbagai bentuk media massa seperti televisi, radio, surat kabar, majalah dan lainnya mempunyai pengaruh besar dalam pembentukkan opini dan kepercayaan orang.

\section{KESIMPULAN DAN SARAN}

\section{Kesimpulan}

Berdasarkan hasil pembahasan, maka dapat diambil kesimpulan yaitu 1) respons petani terhadap program AUTP dilihat dari aspek pemahaman, penerimaan dan pelaksanaan menunjukkan bahwa respons petani berada pada kategori sangat tidak setuju. Hanya sebagian yang berada pada kategori setuju. Hal ini dikarenakan sebagian besar petani responden belum mengikuti program. 2) Faktor-faktor yang dapat mempengaruhi respons petani terhadap program
AUTP antara lain umur, pendidikan formal, pendidikan non formal, pendapatan, pengalaman pribadi, luas lahan garapan dan akses media massa. Namun dalam kategorinya mayoritas bereda pada kategori sangat rendah, hanya umur yang berada pada kategori tengah baya, pendapatan yang berada pada kategori rendah dan akses media massa pada kategori tidak pernah. 3) Faktor-faktor yang berpengaruh signifikan terhadap respons petani adalah umur, pendidikan non formal, pendapatan, pengalaman pribadi, luas lahan garapan dan akses media massa. Faktor lain yang tidak berpengaruh signifikan terhadap respons petani adalah pendidikan formal.

\section{Saran}

Berdasarkan hasil pembahasan dan kesimpulan pada penelitian ini dapat diajukan saran yaitu 1) perlu adanya sosialisasi dan penyuluhan yang lebih intensif terhadap semua kalangan petani tidak hanya perwakilan beberapa anggota dari satu kelompok tani yang ada. 2) Penggunaan media massa dalam menyebarkan informasi program AUTP dengan menggunakan leaflet/brosur ke rumah-rumah petani. Ataupun dengan memasang baliho tentang program AUTP di pinggir-pinggir jalan desa. Selain itu, penyebaran melalui media elektronik seperti televisi dan radio yang tidak hanya skala lokal tetapi juga nasional. 3) Penyuluh, apartur desa dan ketua gapoktan agar lebih bisa meningkatkan antusias petani dalam mengikuti sosialisasi dan penyuluhan pertanian terutama yang berkaitan dengan program AUTP. Selain itu, petani sebagai penerima manfaat program juga perlu meningkatkan kesadarannya terkait pentingnya program sehingga harapannya program mengarah sesuai tujuannya.

\section{DAFTAR PUSTAKA}

Ahmadi, A. 2009. Psikologi Sosial. Jakarta: Rineka Cipta.

Alghifari. 2000. Analisis Regresi: Teori, Kasus, dan Solusi. Yogyakarta: BPFE-Yogyakarta.

Azwar, S. 2013. Sikap Manusia Teori dan Pengukurannya. Yogyakarta: Pustaka Pelajar.

Badan Pusat Satistik. 2018. Kecamatan Adimulyo dalam Angka. BPS Kecamatan 
Ban,V., dan Hawkins. 1999. Penyuluhan Pertanian. Yogyakarta: Kanisius

Budianto, H. 2016. Respon Anggota Kelompok Tani terhadap Program Pengembangan Usaha Agribisnis Perdesaan (PUAP) di Kecamatan Kebun Tebu Kabupaten Lampung Barat. Skripsi. Fakultas Pertanian Universitas Lampung Bandar Lampung.

Dinas Pertanian dan Ketahanan Pangan Kabupaten Kebumen. 2017. Data Luas Lahan yang Diasuransikan Usahatani Padi di Kabupaten Kebumen. Kebumen.

Djunedi, P. 2016. Analisis Asuransi di Indonesia: Konsep, Tantangan dan Prospek. Jurnal Borneo Administrator, 12 (1): 9-27.

Enjolras G, Capitanio F dan Adinolfi F. 2012. The Demand for Crop Insurance: Combined Approaches for France and Italy. Agricultural Economics Review, 5 (13): 1.

Farzaneh M, Allahyari MS, Damalas CA, dan Seidavi A. 2017. Crop insurance as a risk management tool in agriculture: The case of silk farmers in northern Iran. Journal Land Use Policy, 64: 225-232.

Ghozali, I. 2001. Aplikasi Analisis Multivariate dengan program SPSS. Semarang : $\mathrm{BP}-$ UNDIP.

Kementrian Pertanian. 2017. Pedoman Bantuan Premi Asuransi Usahatani Padi.

Jakarta: Direktorat Jenderal Prasarana dan Sarana Pertanian.

Mardikanto, T. 2009. Sistem Penyuluhan Pertanian. Surakarta: UNS Press.

Mulyanti dan Fachrurozi. 2016. Analisis Sikap dan Perilaku Masyarakat terhadap Pelaksanaan Program Bank Sampah (Studi Kasus Masyarakat Kelurahan Bahagia Bekasi Utara). Jurnal Ilmiah Ekonomi Manajemen dan Kewirausahaan "Optimal", 10 (2) : 185-198.

Novia, AR. 2011. Respon Petani terhadap Kegiatan Sekolah Lapangan Pengelolaan Tanaman Terpadu (SLPTT) di Kecamatan Ajibarang Kabupaten Banyumas. Jurnal Ilmu-ilmu Pertanian "Mediagro" 7 (2): 48-60.
Nurhananto DA dan Mutiara F. 2016. Respon Petani Padi terhadap Asuransi Pertanian di Kecamatan Kepanjen Kabupaten Malang. Prosiding Seminar Nasional Pembangunan Pertanian: 454-458. Universitas Tribhuana Tunggadewi Malang.

Pasaribu, SM. 2010. Developing rice farm insurance in Indonesia. Agriculture and Agricultural Science Procedia, 1: 33-41.

Rozalina dan Tusiah. 2015. Faktor-faktor yang Mempengaruhi Respon Petani terhadap Penggunaan Mesin Perontok (Power Thresher) Padi (oryza sativa, L) di Kecamatan Peunaron Kabupaten Aceh Timur. Jurnal Penelitian Agrisamudra, 2(1): 31-40.

Siswandi B dan Syakir F. 2016. Respon Petani erhadap Program Pemerintah Mengenai Asuransi Usahatani Padi (AUTP). Prosiding Seminar Nasional Pembangunan Pertanian: 169-177. Universitas Islam Malang.

Soekartawi. 1988. Analisis Usahatani. Jakarta: UI Press.

Sugiyono. 2013. Metode Penelitian Kuantitatif, Kualitatif, dan R\&D. Bandung: Alfabeta.

Sumaryanto dan A.R Nurmanaf. 2007. Simpulsimpul Strategis Pengembangan Asuransi Pertanian untuk Usaha Tani Padi di Indonesia. Forum Penelitian Agro Ekonomi, 25(2): 89-103.

Suratiyah, K. 2009. Ilmu Usahatani. Depok: Penebar Swadaya.

Tsikirayi CM, Makoni E dan Matiza J. 2013. Analysis of The Uptake of Agricultural Insurance Services by The Agricultural Sector in Zimbabwe. Journal of International Business and Cultural Studies: 1-14.

Wijayanti, A., Subejo dan Harsoyo. 2015. Respons Petani terhadap Inovasi Budidaya dan Pemanfaatan Sorgum di Kecamatan Srandakan Kabupaten Bantul. Jurnal Agro Ekonomi 26 (2):179-191. 